\title{
ДОСЛІДЖЕННЯ ТЕПЛОВОГО БАЛАНСУ СВІТЛОПРОЗОРИХ КОНСТРУКЦІЙ
}

\section{RESEARCH OF THERMAL BALANCE OF TRANSPARENT DESIGNS}

\author{
Пахолюк О.А., к.т.Н., доц., Чапюк О.С., к.т.Н., доц., Дячук Ю.І., \\ магістр (Луцький національний технічний університет, м. Луцьк)
}

\author{
Pakholiuk O.A., Ph.D. in Engineering, Associate Professor, Chapiuk \\ O.S., Ph.D. in Engineering, Associate Professor, Diachuk Y.I., Master \\ (Lutsk National Technical University, Lutsk).
}

Проаналізовано розвиток нормативних документів Украӥни щуодо енергоефективності стосовно євроінтеграційних процесів. Із врахуванням теплового балансу будівлі виділено ряд конструкцій та систем, які мають безпосередній вплив на цей параметр. Досліджено вплив базових параметрів світлопрозорих конструкиій у варіантах, які найчастіше зустрічаються $у$ практищі, на їх тепловий баланс.

The energy independence of each state is one of the most important components of national and economic security. The country's ability to provide the economy and consumers with fuel and energy resources in sufficient quantities to ensure their efficient operation depends on this.

In its move to association with the European Union, Ukraine has made certain commitments under the Protocol of Accession of Ukraine to the Treaty establishing the Energy Community.

Implementing the provisions of the Energy Community, all EU directives and regulations on energy efficiency will enable Ukraine to benefit from the experience gained, reduce the time to develop national legislation and receive effective technical and financial support from the European Union and member states, open new sectors of the economy and create hundreds of thousands of new ones. jobs, providing consumers with better services at a lower price. A number of laws and by-laws have been adopted in Ukraine to implement Directive 2010/31 / EU.

Energy consumption of buildings largely depends on the parameters of the microclimate of premises and buildings in general. Temperature, ventilation and lighting parameters are used in design and operation. They also affect the health, productivity and comfort of the people in the room.

The calculation of the energy balance (difference between heat and heat loss) of the building is a serious tool for analyzing the energy efficiency of the building. Windows as the least protected from energy loss have great potential to increase energy efficiency. Therefore, it is advisable to study the energy balance of translucent structures of the building depending on their energy efficiency characteristics. 


\section{"Сучасні технології та методи розрахунків у будівництві", випуск 14, 2020}

Determining the energy balance of a building in Ukraine is carried out in accordance with national standards. By types, the energy balance can be divided into energy (thermal) balance of the building level and at the system level. The input data for calculating the energy balance of heating, cooling and ventilation systems are energy needs for explicit heat. The calculation method in national standards is limited to heating and cooling by apparent heat. The calculation of the energy balance was performed for each window on a monthly basis and summarized within the annual heat balances.

Ключові слова: директива ЄC, енергоспоживання, мікроклімат, енергетичний баланс.

Keywords: EU directive, energy consumption, microclimate, energy balance.

\section{Огляд літературних джерел за вибраною темою досліджень.} Енергетична незалежність кожної держави $є$ однією 3 найважливіших складових національної і економічної безпеки. Від цього залежить можливість країни забезпечити економіку та споживачів паливноенергетичними ресурсами в кількості, достатній для того, щоб забезпечити їх ефективну діяльність.

У своєму русі до асоціації з Європейським союзом Україна взяла на себе деякі зобов'язання в рамках Протоколу [2].

«Після 20 років розробки та впровадження у ЄС трьох хвиль енергетичного законодавства накопичено чималий практичний досвід реалізації програм, які Україна мусить впровадити в значно коротший час, але за наявності незрівнянно менших ресурсів - як фінансових, так i людських. Проблема високих втрат у будівлях, що сягають 50-80\%, вимагає певної пріоритетизації дій - скорочення потреби і споживання, за якими вже слід сконцентруватися на заміщенні традиційних джерел енергії альтернативним, а не навпаки» [8].

«Виконання всіх положень Енергетичного Співтовариства, директив та регламентів СС 3 енергоефективності надасть Україні можливість скористатися напрацьованим досвідом, скоротити час на розроблення національного законодавства та отримати дієву технічну та фінансову підтримку з боку Свропейського Союзу та країн-членів, відкриє нові сектори економіки та створить сотні тисяч нових робочих місць, забезпечивши споживачів якіснішими послугами за нижчу ціну. Виконання наближеного законодавства Україною потребує створення спроможності з його впровадження, а отже потребує кадрового потенціалу та розуміння причин прийняття законодавчих актів i ïx внутрішньої логіки» [8].

«Держенергоефективності в свою чергу відповідно до зобов'язань, взятих Україною відповідно до Угоди про асоціацію між Україною, 3 однісї сторони, та Свропейським Союзом, Свропейським співтовариством з атомної енергії і їхніми державами-членами, з іншої сторони (далі - 


\section{"Сучасні технології та методи розрахунків у будівництві", випуск 14, 2020}

Угода про асоціацію), а також у рамках Протоколу про приєднання до Договору про заснування Енергетичного Співтовариства, ратифікованого Законом України від 15 грудня 2010 року № 2787-VI «Про ратифікацію Протоколу про приєднання України до Договору про заснування Енергетичного Співтовариства», здійснює заходи щодо імплементації у національне законодавство вимог профільної Директиви Європейського Парламенту та Ради СС 2012/27/СС про енергетичну ефективність, яка інкорпорована в законодавство Енергетичного Співтовариства відповідно до рішення Ради Міністрів Енергетичного Співтовариства від 15 жовтня 2015 року № 2015/08/MC-EnC та Директиви Свропейського Парламенту та Ради 2010/31/СС від 19 травня 2010 року про енергетичну ефективність будівель» [3].

На виконання Директиви 2010/31/СС [1] в Україні було прийнято ряд законів та підзаконних актів [4-7].

Енергоспоживання будівель значною мірою залежить від параметрів мікроклімату приміщень та будівель загалом. Параметри температури, вентиляції i освітлення використовуються при проектуванні та експлуатації. Вони також мають вплив на здоров'я та комфорт людей у приміщенні $[9,10]$.

Мікрокліматом приміщень називають «умови внутрішнього середовища цих приміщень, що впливають на тепловий обмін працюючих 3 оточенням шляхом конвекції, кондукції, теплового випромінювання та випаровування вологи. Ці умови визначаються поєднанням температури, відносної вологості та швидкості руху повітря, температури оточуючих людину поверхонь та інтенсивністю теплового (інфрачервоного) опромінення» [9].

Дані досліджень свідчать, що вартість впливу поганого мікроклімату на працівників, власників будівлі та суспільство в цілому часто є значно більшою, ніж вартість енергії для експлуатації цього ж будинку. Крім того, при недостатньому рівні комфорту люди стараються щось робити для його підвищення. Це також може мати вплив на перевитрати енергії.

Розрахунок енергетичного балансу (різниці теплонадходжень та тепловтрат) будівлі $\epsilon$ серйозним інструментом для аналізу енергоефективності будівлі. Вікна як найменш захищені від втрат енергії мають великий потенціал до підвищення рівня енергоефективності. Тому доцільно провести дослідження енергетичного балансу світлопрозорих конструкцій будівлі в залежності від їх енергоефективних характеристик.

Методика дослідження. Визначення енергетичного балансу будівлі в Україні ведеться згідно з національними стандартами $[11,12]$.

За видами енергетичний баланс можна поділити на енергетичний (тепловий) баланс рівня будівлі і на рівні систем. Вхідними даними для розрахунку енергобалансу систем опалення, охолодження та вентиляції $€$ 


\section{"Сучасні технології та методи розрахунків у будівництві", випуск 14, 2020}

енергопотреби за явною теплотою. Методика розрахунку у національних нормах обмежена опаленням та охолодженням.

«Енергетичний (тепловий) баланс рівня зони будівлі включає наступні складові:

- трансмісійну теплопередачу між кондиціонованим об'ємом та зовнішнім навколишнім середовищем, що обумовлена різницею між температурою кондиціонованої зони та температурою зовнішнього повітря;

- вентиляційну теплопередачу (від природної вентиляції або системи механічної вентиляціi), спричинену різницею між температурою кондиціонованої зони та температурою припливного повітря;

- внутрішні теплонадходження (включаючи від'ємні надходження від тепловідводу), від людей, устаткування, освітлення та теплота, що виділена або поглинута з систем опалення, охолодження, ГВП, вентиляції тощо;

- сонячні теплонадходження (які можуть бути прямими, наприклад, через вікна, або непрямими, наприклад, поглинені непрозорими елементами будівлі);

- акумульовану теплоту в будівлі або вивільнений запас теплоти 3 масиву будівлі;

- енергопотребу для опалення: якщо зона опалюється, система опалення постачає теплоту для підвищення внутрішньої температури до мінімально необхідного рівня (завданого для опалення);

-енергопотребу для охолодження: якщо зона охолоджується, система охолодження відбирає теплоту для зниження внутрішньої температури до максимально необхідного рівня (завданого для охолодження)» [11].

«Місячний метод розрахунку в цьому стандарті базується на застосуванні коефіцієнта використання, в якому місячні енергопотреби для опалення розраховують, як різницю між місячною теплопередачею за рахунок трансмісії та вентиляції та місячною сумою надходжень від внутрішніх і сонячних джерел, помноженою на коефіцієнт використання надходжень» [11].

Енергопотребу для опалення при постійному опаленні для кожної зони і кожного місяця розраховують за формулою [11]:

$$
Q_{H, n d}=Q_{H, n d, \text { cont }}=Q_{H, h t}-\eta_{H, g n} Q_{H, g n}
$$

де $\mathrm{Q}_{\mathrm{H}, \mathrm{nd}, \mathrm{cont}}$ - енергопотреба, Вт год;

$\mathrm{Q}_{\mathrm{H}, \mathrm{ht}}$ - сумарна теплопередача, Вт год;

$\mathrm{Q}_{\mathrm{H}, \mathrm{gn}}$ - сумарні теплонадходження, Вт год;

$\eta_{\mathrm{H}, \mathrm{gn}}$ - безрозмірний коефіцієнт використання надходжень.

Енергопотребу для охолодження при постійному охолодженні для кожної зони і кожного місяця розраховують за формулою [11]: 


$$
Q_{C, n d}=Q_{C, n d, \text { cont }}=Q_{C, \text { gn }}-\eta_{C, l s} Q_{C, h t}
$$

де $\mathrm{Q}_{\mathrm{C}, \mathrm{nd}, \mathrm{cont}}$ - енергопотреба для охолодження, Вт год;

$\mathrm{Q}_{\mathrm{C}, \mathrm{ht}}$ - сумарна теплопередача, Вт год;

$\mathrm{Q}_{\mathrm{C}, \mathrm{gn}}$ - сумарні теплонадходження, Вт год;

$\eta_{\mathrm{C}, \mathrm{gn}}$ - безрозмірний коефіцієнт використання втрат.

3 огляду на те, що енергобаланс будемо визначати не для всієї будівлі загалом, а лише для світлопрозорих конструкцій i вони достатньо повітронепроникні, втрати будемо визначати як сумарну теплопередачу трансмісією через зону будівлі (в період опалення і охолодження), а надходження - як сонячні теплонадходження.

Сумарна теплопередача трансмісією розраховують для кожного місяця за формулами:

- для опалення:

$$
Q_{t r}=H_{t r, a d j}\left(\theta_{\text {int, set }, H}-\theta_{c}\right) t
$$

- для охолодження:

$$
Q_{t r}=H_{t r, a d j}\left(\theta_{\text {int,set }, C}-\theta_{c}\right) t
$$

де $\mathrm{H}_{\mathrm{tr}, \mathrm{adj}}$ - коефіцієнт теплопередачі трансмісією, Вт/К;

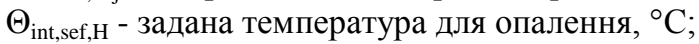

$\Theta_{\mathrm{int}, \mathrm{sef}, \mathrm{C}}$ - задана температура для охолодження, ${ }^{\circ} \mathrm{C}$;

$\Theta_{\mathrm{C}}$ - середньомісячна температура середовища зовні, ${ }^{\circ} \mathrm{C}$;

t - тривалість місяця, год.

Загальна теплопередача трансмісією буде сумою значень для періоду опалення і охолодження.

«Джерелом теплових надходжень від сонця є сонячна радіація, режим якої характерний у даній місцевості, та визначається орієнтацією сприймаючих поверхонь, постійним чи рухомим затіненням, пропусканням та поглинанням сонячної енергії й характеристиками теплопередачі сприймаючих поверхонь. Коефіцієнт, що включає характеристики та площу сприймаючих поверхонь (включно з впливом затінення), називається еквівалентною площею інсоляції» [11].

Теплонадходження від сонця для кожного місяця:

$$
Q_{s o l}=\left(\sum_{k} \Phi_{s o l, m n, k}\right) t
$$

де $\Phi_{\mathrm{sol}, \mathrm{mn}, \mathrm{k}}$ - тепловий потік від джерела сонячного випромінювання, Вт;

$\mathrm{t}$ - тривалість розрахункового місяця місяця, год.

Сонячні теплонадходження через елемент будівлі:

$$
\Phi_{s o l, k}=F_{s h, o b, k} A_{s o l, k} I_{s o l, k}-F_{r, k} \Phi_{r, k}
$$


де $\mathrm{F}_{\mathrm{sh}, \mathrm{ob}, \mathrm{k}}$ - понижувальний коефіцієнт затінення перешкодами;

$\mathrm{A}_{\mathrm{sol}, \mathrm{k}}$ - еквівалентна площа інсоляції, $\mathrm{m}^{2}$;

$1_{\text {sol,k }}$ - сонячна радіація, Вт/м²;

$\mathrm{F}_{\mathrm{r}, \mathrm{k}}$ - коефіцієнт форми;

$\Phi_{\mathrm{r}, \mathrm{k}}$ - додатковий тепловий потік.

Для розрахунків було прийнято ряд вікон із найтиповішими характеристиками.

Таблиця 1

Вибрані для розрахунків вікна

\begin{tabular}{|c|c|c|c|c|}
\hline & $\begin{array}{c}\text { Товщина } \\
\text { профілю, } \\
\text { мм }\end{array}$ & $\begin{array}{c}\text { Товщина } \\
\text { склопакета, } \\
\text { мм }\end{array}$ & Формула склопакета & $\begin{array}{c}\text { Приведений опір } \\
\text { теплопередачі } \\
\text { вікна, (м }{ }^{2} \text { K)/Bт }\end{array}$ \\
\hline & 60 & 24 & $4-16-4$ & 0,38 \\
\hline & 70 & 40 & $4-14-4-14-4$ & 0,52 \\
\hline & 70 & 32 & $4-10-4-10-4 \mathrm{i}$ & 0,61 \\
\hline & 70 & 32 & $4 \mathrm{i}-10-4-10-4 \mathrm{i}$ & 0,72 \\
\hline & 70 & 40 & $4-14 \mathrm{Ar}-4-14 \mathrm{Ar}-4 \mathrm{i}$ & 0,78 \\
\hline & 70 & 40 & $4 \mathrm{i}-14-4-14-4 \mathrm{i}$ & 0,86 \\
\hline & 80 & 44 & $4 \mathrm{i}-14 \mathrm{Ar}-4-14 \mathrm{Ar}-4 \mathrm{i}$ & 1,03 \\
\hline & 80 & 52 & $4 \mathrm{i}-16 \mathrm{Ar}-4-16 \mathrm{Ar}-4 \mathrm{i}$ & 1,28 \\
\hline 0 & 80 & 44 & $4 \mathrm{i}-\mathrm{T} 20 \mathrm{Ar}-4-$ & 1,31 \\
\hline
\end{tabular}

Розрахункові параметри вікон наведені у табл. 2.

Розрахунок теплового балансу проведено для кожного вікна помісячно і зведено в межах річних теплових балансів.

Результати. Отримані результати для всіх типів вікон зведено у табл. 3 .

\section{Висновки}

1. При збільшенні товщини профіля і склопакета, додаванні напилення на скло та інертних газів у камеру їх опір теплопередачі зростає.

2. Сонячні теплонадходження залежать від кількості листів скла у склопакеті та наявності напилення на них. Географічне розташування, пора року та орієнтація за сторонами світу також впливають на цей показник.

3. Сумарна теплопередача трансмісією залежить від опору теплопередачі вікна. При збільшенні опору теплопередача зменшується. Вона буде також залежати від зовнішніх умов у період опалення та охолодження будівлі.

4. Тепловий баланс для віконних конструкцій при збільшенні опору теплопередачі зміщується у бік збільшення. При певних значеннях опору він долає відмітку 0 і набуває додатних значень. Вікна з позитивним тепловим балансом мають опір теплопередачі, який відповідає чинним нормам. 
"Сучасні технології та методи розрахунків у будівництві", випуск 14, 2020

Таблиця 2. Розрахункові параметри вікон

\begin{tabular}{|c|c|c|c|c|c|c|c|c|c|c|c|c|}
\hline 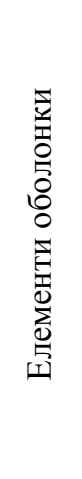 & $\begin{array}{l}\text { 目 } \\
\hat{\hat{H}} \\
\dot{1} \\
\dot{1}\end{array}$ & & & 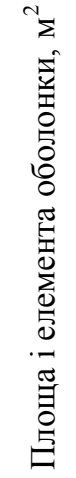 & 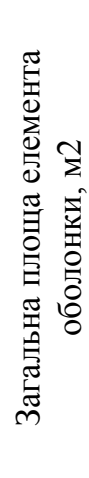 & 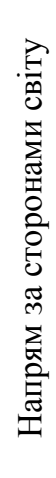 & 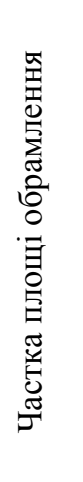 & 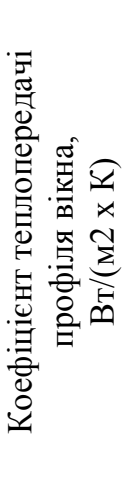 & 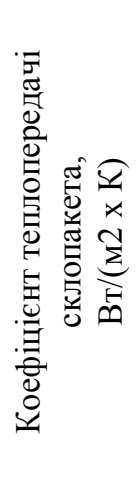 & 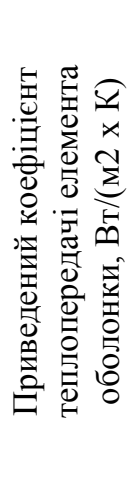 & 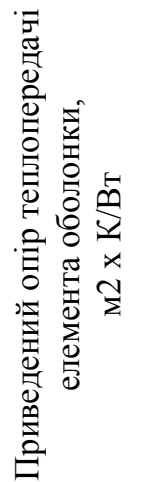 & 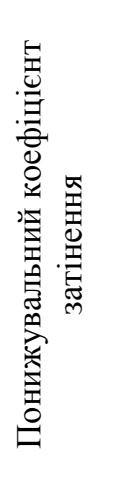 \\
\hline ВК1 & 6 & 1,3 & 2,7 & 3,51 & 21,06 & $\Pi_{\mathrm{H}}$ & 0,37 & 1,63 & 3,13 & 2,857 & 0,35 & 0,86 \\
\hline ВК2 & 25 & 4,8 & 1,5 & 7,20 & 180 & Пн & 0,16 & 1,63 & 3,13 & 3,015 & 0,332 & 0,86 \\
\hline ВК1 & 22 & 1,3 & 2,7 & 3,51 & 77 & $\mathrm{Cx}$ & 0,37 & 1,63 & 3,13 & 2,857 & 0,35 & 0,86 \\
\hline ВК2 & 18 & 4,8 & 1,5 & 7,20 & 130 & $\mathrm{Cx}$ & 0,16 & 1,63 & 3,13 & 3,015 & 0,332 & 0,86 \\
\hline ВК1 & 6 & 1,3 & 2,7 & 3,51 & 21,06 & Пд & 0,37 & 1,63 & 3,13 & 2,857 & 0,35 & 0,86 \\
\hline ВК2 & 25 & 4,8 & 1,5 & 7,20 & 180 & Пд & 0,16 & 1,63 & 3,13 & 3,015 & 0,332 & 0,86 \\
\hline ВК1 & 18 & 1,3 & 2,7 & 3,51 & 63,18 & $3 x$ & 0,37 & 1,63 & 3,13 & 2,857 & 0,35 & 0,86 \\
\hline ВК2 & 18 & 4,8 & 1,5 & 7,20 & 129,6 & $3 x$ & 0,16 & 1,63 & 3,13 & 3,015 & 0,332 & 0,86 \\
\hline
\end{tabular}


"Сучасні технології та методи розрахунків у будівництві", випуск 14, 2020

Таблиця 3. Зведена таблиця теплових балансів

\begin{tabular}{|c|c|c|c|c|c|}
\hline & Пакет & Опір & $\begin{array}{c}\text { Загальні сонячні } \\
\text { теплонадходження, } \\
\text { кВт*год }\end{array}$ & $\begin{array}{c}\text { Сумарна теплопередача } \\
\text { трансмісією, кВт* год }\end{array}$ & $\begin{array}{c}\text { Тепловий баланс, } \\
\text { кВт*год }\end{array}$ \\
\hline 1 & $4-16-4$ & 0,38 & 162876,52 & 240574,83 & $-77698,31$ \\
\hline 2 & $4-14-4-14-4$ & 0,52 & 152018,06 & 175628,77 & $-23610,71$ \\
\hline 3 & $4-10-4-10-4 i$ & 0,61 & 125957,83 & 150016,26 & $-24058,43$ \\
\hline 4 & $4 \mathrm{i}-10-4-10-4 \mathrm{i}$ & 0,72 & 108584,34 & 127147,91 & $-18563,57$ \\
\hline 5 & 4-14Ar-4-14Ar-4i & 0,78 & 125957,83 & 117085,84 & 8871,99 \\
\hline 6 & $4 \mathrm{i}-14-4-14-4 \mathrm{i}$ & 0,86 & 108584,34 & 106109,06 & 2475,28 \\
\hline 7 & $4 \mathrm{i}-14 \mathrm{Ar}-4-14 \mathrm{Ar}-4 \mathrm{i}$ & 0,98 & 108584,34 & 93302,79 & 15281,55 \\
\hline 8 & $4 \mathrm{i}-16 \operatorname{Ar}-4-16 \operatorname{Ar}-4 \mathrm{i}$ & 1,03 & 108584,34 & 88729,11 & 19855,23 \\
\hline 9 & 4i-T20Ar-4-T20Ar-4i & 1,28 & 108584,34 & 78209,67 & 30374,67 \\
\hline 10 & $4 \mathrm{i}-16 \mathrm{Kr}-4-16 \mathrm{Kr}-4 \mathrm{i}$ & 1,31 & 108584,34 & 76380,23 & 32204,11 \\
\hline
\end{tabular}


"Сучасні технології та методи розрахунків у будівництві", випуск 14, 2020
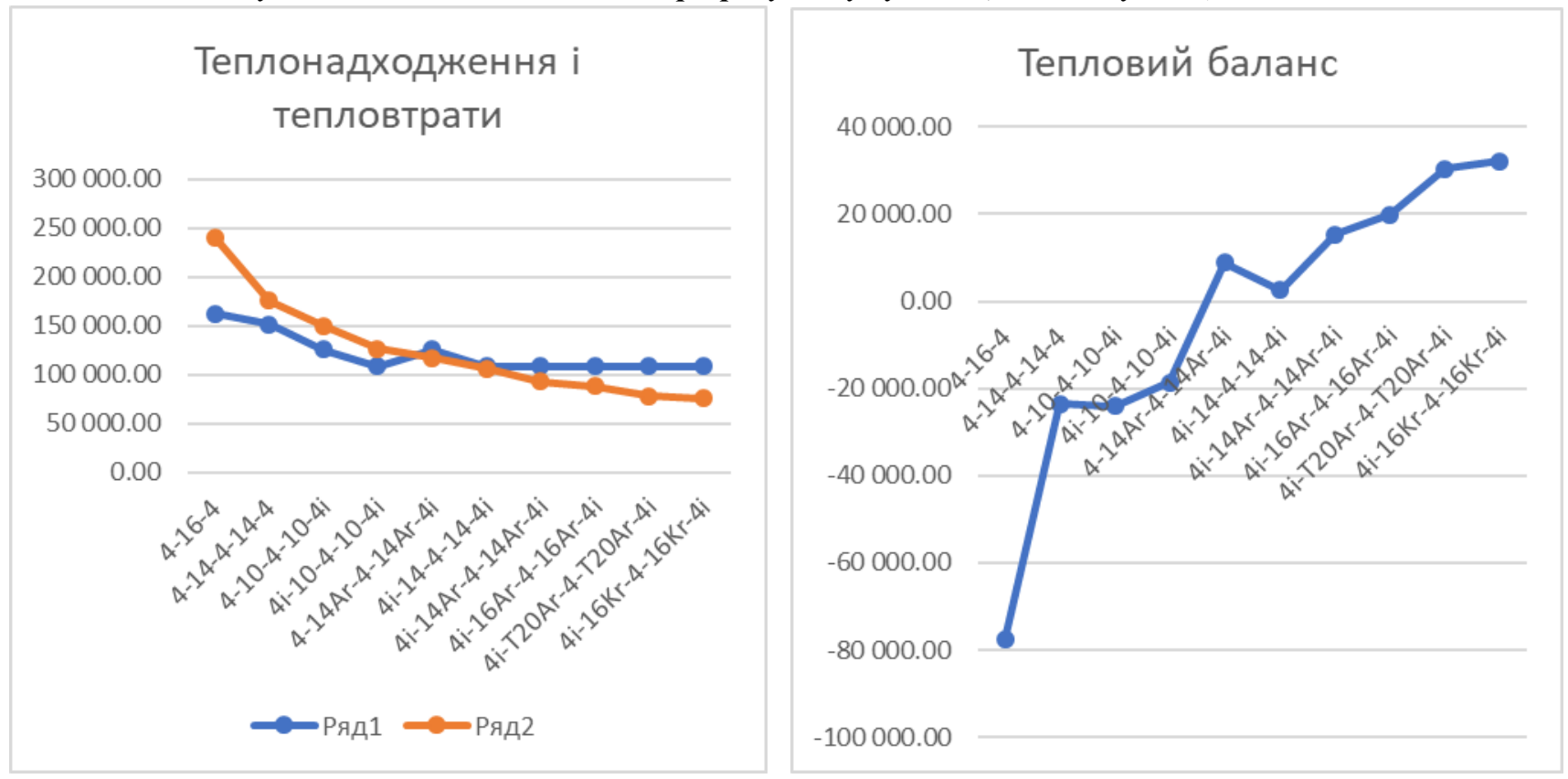


\section{References}

1. Dy`rekty`va 2010/31/ES Yevropejs`kogo Parlamentu ta Rady` vid 19 travnya 2010 r. shhodo energety`chny`x xaraktery`sty`k budivel` (onovlena versiya).

2. Protokol pro pry`yednannya Ukrayiny` do Dogovoru pro zasnuvannya Energety`chnogo Spivtovary`stva Rezhy'm dostupu: https://zakon.rada.gov.ua/laws/show/994_a27\#Text.

3. Yevropejs`ka integraciya. Rezhym dostupu: https://www.saee.gov.ua/uk/activity/mizhnarodne-spivrobitnytstvo/eu-integration.

4. Zakon Ukrayiny` «Pro energety`chnu efekty`vnist' budivel'».

5. Poryadok provedennya profesijnoyi atestaciyi osib, yaki mayut namir provady`ty` diyal`nist` iz serty`fikaciyi energety`chnoyi efekty`vnosti ta obstezhennya inzhenerny`x sy`stem, zatverdzheny`j postanovoyu Kabinetu Ministriv Ukrayiny`vid 26.07.2018 \# 605.

6. Poryadok vedennya baz dany`x zvitiv pro rezul'taty' obstezhennya inzhenerny` $x$ sy`stem, atestovany` $x$ energoaudy`toriv ta faxivciv $z$ obstezhennya inzhenerny`x sy`stem, energety`chny`x serty`fikativ, zatverdzheny`j nakazom Minregionu vid 21.03.2018 \# 62.

7. Poryadok nezalezhnogo monitory`ngu energety`chny`x serty`fikativ budivel’, zatverdzheny`j nakazom Minregionu vid 18.10.2018 \# 276.

8. S. Pavlyuk, R. Xorol`s`ky`j Spivrobitny`cztvo mizh Ukrayinoyu ta Yevropejs`ky'm Soyuzom u sferi energoefekty`vnosti, Ky'yiv.: GO "Laboratoriya zakonodavchy`x iniciaty`v“, 2015. Rezhy`m dostupu: https://parlament.org.ua/wpcontent/uploads/2018/03/2.pdf

9. DSN 3.3.6.042-99 Sanitarni normy` mikroklimatu vy`robny`chy`x pry`mishhen` Rezhy`m dostupu: https://zakon.rada.gov.ua/rada/show/va04228299\#Text.

10. DSTU B EN 15251:2011. Rozraxunkovi parametry` mikroklimatu pry ‘mishhen` dlya proektuvannya ta ocinky` energety`chny`x xaraktery`sty`k budivel` po vidnoshennyu do yakosti povitrya, teplovogo komfortu, osvitlennya ta akusty`ky` (EN 15251:2007, IDT).

11. DSTU B A.2.2-12:2015 Energety`chna efekty`vnist' budivel`. Metod rozraxunku energospozhy`vannya pry`opalenni, oxolodzhenni, venty`lyaciyi, osvitlenni ta garyachomu vodopostachanni.

12. DSTU B EN ISO 13790:2011 Energoefekty`vnist` budy`nkiv. Rozraxunok energospozhy`vannya na opalennya ta oxolodzhennya (EN ISO 13790:2008, IDT).

\section{Список використаної літератури}

1. Директива 2010/31/ЕС Європейського Парламенту та Ради від 19 травня 2010 р. щодо енергетичних характеристик будівель (оновлена версія). 
2. Протокол про приєднання України до Договору про заснування Енергетичнго Співтовариства Режим доступу: https://zakon.rada.gov.ua/laws/show/994_a27\#Text.

3. Свропейська інтеграція. Режим доступу: https://www.saee.gov.ua/uk/activity/mizhnarodne-spivrobitnytstvo/eu-integration.

4. Закон України «Про енергетичну ефективність будівель».

5. Порядок проведення професійної атестації осіб, які мають намір провадити діяльність із сертифікації енергетичної ефективності та обстеження інженерних систем, затверджений постановою Кабінету Міністрів України від 26.07.2018 № 605 .

6. Порядок ведення баз даних звітів про результати обстеження інженерних систем, атестованих енергоаудиторів та фахівців з обстеження інженерних систем, енергетичних сертифікатів, затверджений наказом Мінрегіону від 21.03.2018 № 62 .

7. Порядок незалежного моніторингу енергетичних сертифікатів будівель, затверджений наказом Мінрегіону від 18.10.2018 № 276.

8. С. Павлюк, Р. Хорольський Співробітництво між Україною та Європейським Союзом у сфері енергоефективності, Київ.: ГО “Лабораторія законодавчих ініціатив“, 2015. Режим доступу: https://parlament.org.ua/wpcontent/uploads/2018/03/2.pdf

9. ДСН 3.3.6.042-99 Санітарні норми мікроклімату виробничих приміщень Режим доступу: https://zakon.rada.gov.ua/rada/show/va042282-99\#Text.

10. ДСТУ Б EN 15251:2011. Розрахункові параметри мікроклімату приміщень для проектування та оцінки енергетичних характеристик будівель по відношенню до якості повітря, теплового комфорту, освітлення та акустики (EN 15251:2007, IDT).

11. ДСТУ Б А.2.2-12:2015 Енергетична ефективність будівель. Метод розрахунку енергоспоживання при опаленні, охолодженні, вентиляції, освітленні та гарячому водопостачанні.

12. ДСТУ Б EN ISO 13790:2011 Енергоефективність будинків. Розрахунок енергоспоживання на опалення та охолодження (EN ISO 13790:2008, IDT). 